\title{
An Exploratory Study of Muslim Consumers' Expectation of an Islamic-Based Retail Store and Their Patronage Motive
}

\author{
Waida Irani Mohd Fauzi ${ }^{\text {** }}$, Sany Sanuri Mohd Mokhtar ${ }^{\mathrm{a}}$, Rushami Zien \\ Yusoff $^{\mathrm{a}}$ \\ * Corresponding author: Waida Irani Mohd Fauzi, waida@uum.edu.my \\ ${ }^{a}$ School of Business Management, Universiti Utara Malaysia, Sintok, Kedah.Malaysia
}

\begin{abstract}
http://dx.doi.org/10.15405/epsbs.2016.08.103

A recent trend in the Malaysian retail industry is the growing Malaysian Muslim consumers' conservatism, and the need to adopt to the Islamic way of life. Stores are adjusting retail elements to suit Islamic cultures and values to win the heart of Muslim consumers. The phenomenon of religious customization of retail outlets has not been explored in marketing areas, and thus little is understood on consumers' patronage motives and their expectations of retail Islamic stores. The aims of this study are twofold: to explore Malaysian Muslim consumers' expectations of an Islamic-based retail store; and their motive to patronize an Islamic-based retail store. Interviews performed in the Northern region of Malaysia suggests unique religion-related motives to patronage of the stores. Findings show respondents have unique expectations on retail stores, besides the contemporary factors as reported in the mainstream retailing studies. This study shares some initial insight into criteria for Islamic retail-based segmentation for Muslim consumers. Implications and limitations of the study are also discussed.
\end{abstract}

(C) 2016 Published by Future Academy www.FutureAcademy.org.uk

Keywords: Store attributes; patronage behaviour; Muslim consumer; Islamic; positioning and retailing.

\section{Introduction}

The Malaysian retail industry The Malaysian retail industry is witnessing a growing interest for retailers to cater to Muslim consumers' increasing need to comply with Islamic teachings in their purchasing behaviors. The Malaysian marketplace is currently witnessing a trend amongst businesses to meet increasing demands for Syariah compliant products and services (John Dawson, Findlay \& Paddison, 2005). Growing religious conservatism and appreciation of Islamic values in markets like 
Malaysia offer unique opportunities for retailers to offer more "Islamically" customized products and services. This study explores Muslim consumers' expectations for an Islamic retail store, and identifies Muslim consumers' motivations to patronize an Islamic retail store. Knowledge in this area adds to the literature on the religious segment of retail store outlets, and may assist marketers who choose to market to this segment.

\section{Literature Review}

Prior studies showed that there are differences between intrinsic religious (devout) and extrinsic religious (casual) consumers in their marketplace behaviors (e.g.: (Essoo \& Dibb, 2004; Sood \& Nasu, 1995). Delener (1990) categorized types of purchasing decisions according to consumers' adherence to their religious teachings. In fact, consumers' adherence to their religion (commitment) explains the evaluation criteria used to determine retail store patronage (McDaniel \& Burnett, 1990) and store loyalty (Swimberghe et al., 2009).

Intrinsically religious people tend to be store-loyal consumers, have low switching behavior, and have high tendency to patronize a store with hold similar values that suit their lifestyles (Choi, 2010; Choi, Kale, \& Shin, 2010; Shabbir, 2010). They show more preference toward local brands and become more ethnocentric in purchasing locally made products (Fam, Waller \& Erdogan, 2004). Intrinsic Muslims are more ethnic-conscious, place greater emphasis on family values, are conservative and not evolved significantly to modernity, and adopt traditional beliefs and values in daily lives (Mokhlis, 2009).

\subsection{Islamic Retail store attributes and behavior}

\subsubsection{Halal Product Certification}

Recently, halal issues have been brought to the attention of Muslim consumers; they have become aware of the halal aspect specifically when they choose a food product. It is becoming a common practice by Muslim consumers to look for halal logos and verifiable halal certificates while buying. By having a halal logo, it is proven that a product is religiously allowable. By considering this element, it is becoming an important consideration in patronizing a store. The increasing interest in halal product awareness is due to the changing preferences and tastes among Muslim consumers to fulfill their religious obligations as a Muslim (Wan Hassan \& Awang, 2009). The easiest way to identify whether the product is halal is based on halal symbols or halal certification by a trusted authority. Muslims in Malaysia have positive attitudes and consciousness about halal products which positively influences their intention to purchase (Hanzaee, 2011). Additionally, the study stresses that halal is an important dimension to influence grocery shoppers to patronize retail outlets in Malaysia (Abu \& Roslin, 2008).

\subsubsection{Islamic Values}

Muslim consumers assess and appreciate retailers that tend to practice values that are aligned with Islamic teachings and values. The set of values Muslim consumers use to assess a retailer before deciding to patronize the store tend to be unique to the group (Ahmad \& Kadir, 2013); Gayatri, 2010). 
http://dx.doi.org/10.15405/epsbs.2016.08.103

eISSN: 2357-1330 / Corresponding Author: Waida Irani Mohd Fauzi

Selection and peer-review under responsibility of the Organizing Committee of the conference

Alongside the common retail store determinant factors, "Islamic value" is the predominant criteria by which Muslim consumers evaluate a store.Retailers who practice Islamic values will conduct their businesses as derived from the teachings of the Quran and Sunnah (sayings of the Prophet Muhammad). Their ultimate goals for a business are not primarily materialistic, but tend towards human well-being and a life that emphasizes brotherhood and socioeconomic justice as a required balance for both material and spiritual needs of humanity.

\subsubsection{Muslim Product}

Muslim consumers must choose good food (tayyib) and not only focus on halal. In Islam, all products are only considered as good products when they come from the right source, are useful, clean, wholesome, beneficial, morally and ethically and are not in conflict with what is forbidden by Islam. In other words, Muslim consumers are encouraged to find a product where no doubt exists in terms of processing from the beginning until the product is distributed to the customer. All the process must be halal and preferably handled by Muslim workers.Usually, they are known as Islamic brands, which are following Syariah compliant laws. Some of the products originate from an Islamic country, and the brand must be targeted at Muslim consumers (Alserhan, 2010). Muslim consumers may prefer to patronize stores offering more national brands in order to simplify their search for muslim made products.

\subsubsection{Islamic Store atmosphere}

Studies are unanimous on the importance of store atmosphere as a determinant for store patronage (Baker, Parasuraman, Grewal \& Voss, 2002; Mattila \& Wirtz, 2001). Islamic retail store atmospheres that adopt Islamic cultures, traditions or values, could be attractive to Muslim consumers niche markets and in predominantly Muslim markets. For example, the use of Islamic-based music such as melodic zikr (phrases praising God i.e. Allah; (Devine, 2011; Frishkopf, 2009; Sarkissian, 2005), recitation of the Quran, sales personnel with modest outfits, and respect and acknowledgement for Islamic festivals through window decorations

\subsubsection{Humanistic}

Humanistic refers to a person having a strong interest in or concern for human welfare, values and dignity, in particular a personal interaction and in-store service that create to attract customers to a store. Studies suggest personal interaction with salespersons, and the friendliness of the salesperson, influence the patronage behavior of religious people (Abu \& Roslin, 2008; McDaniel \& Burnett, 1990). The fact that they are more dependable and sociable may explain the importance of such peopleoriented attributes such as friendly and helpful sales personnel in their decision making (Mokhlis, 2006, 2009).

\section{Research Method}

A number of customers had been interviewed to explore their patronage motives towards Islamicbased retail outlets based on mall intercept approach. They were asked their motives to visit the store, 
types of products they normally purchase from the store, their impression about shopping at the store, and the store attributes that attracted them to visit the particular store. This study was conducted in northern region of Malaysia where there is a significant growth in Islamic-based retail outlets and industry. There are 14 Islamic retail stores that involved in the study. The study used cluster sampling to identify the store. Ten store patron customers randomly selected from each store to participate in the interviewed.

\section{Findings}

The sample described the prominent motive is to purchase products that are not only halal but also toyyiban (wholesome). There are indications that they have greater confidence of the halal status of products offered at the outlet as well as the feel-good factor of knowing that they are patronizing Muslim-owned outlets.

All respondents were very particular about halal status of products. They choose to patronize the store based on their belief that retail stores that carry Islamic images offer products that are truly halal, or fit for Muslim consumption as compared to others. It appears that many of the respondents have doubts on the halalness of products that are sold in an ordinary supermarket.

"I have more confidence on products that are made and sold by Muslims than those at the supermarkets"

".....I have doubt on the halalness of products sold by ordinary supermarkets... fish ball, fish cakes by non-Muslim products are doubtful... you don't know what are their ingredients... can't take them... fear that its haram."

Respondents' patronage of Islamic-based retail stores is a form of support to Muslim businesses.

“...Muslim products and we want to help our Muslim's business

"We are now more concern on purchasing halal products...in fact some of us will not patronage Tesco, because of its connection with Jews, so this type of store (Islamically positioned store) is good..”

Respondents mentioned that they are looking for products that are halalan toyyiban. The concept is an extended version of halal that stresses the goodness of products. “'Actually, I am concern not only on the halal status of a product but also on the goodness of the product that is the halallan toyibban"

\section{Conclusion}

The most highlighted criteria of muslim consumer expectation of Islamic-based retail stores in this study are: to offer halal not only by certification but in trusted process of achieving halal, muslim made product and store ambience that emphasizes Islamic aesthetic values. Given the explorative nature and limited context of this study, the highlights from this study need further investigation and empirical evidence from larger geographic contexts locally and internationally. Markets with multi-religious 
societies may also benefit from this retail format, especially with the rising appreciation and understanding of the halal concept among non-Muslim consumers.

\section{References}

Abu, N. K., \& Roslin, R. M. (2008). Identifying Service Quality Dimensions By Understanding Consumer Preferences In The Malaysian Grocery Retail Sector. UniTAR e-Journal, 4(2), 57-67.

Ahmad, M., \& Kadir, S. A. (2013). Characteristics of Entrepreneurs and the Practice of Islamic Values in Influencing the Success of Small Medium Enterprises in Kelantan and Selangor. Journal of Social \& Development Sciences, 4(5), 229-35.

Alhemoud. (2008). Shopping behavior of supermarket consumers in Kuwait. Journal of Business \& Economics Research, 6 (3). 1-12.

Alserhan, B. (2010). On Islamic branding: brands as good deeds. Journal of Islamic Marketing, 1(2), 101-106.

Anas Mohd Yunus, W. M. Y. W. C., Mahani Mohamad. (2010). The concept of halalan Tayyibba and its application in products Marketing. International Journal of Business and Social Sciences., 1(3), 239-247.

Baker, J., Parasuraman, A., Grewal, D., \& Voss, G. (2002). The influence of multiple store environment cues on perceived merchandise value and patronage intentions. Journal of Marketing, 66(2), 120-141.

Baltas, G., \& Papastathopoulou, P. (2003). Shopper characteristics, product and store choice criteria: a survey in the Greek grocery sector. International Journal of Retail \& Distribution Management, 31(10), 498-507.

Choi, Y. (2010). Religion, religiosity, and South Korean consumer switching behaviors. Journal of Consumer Behaviour, 9(3), 157-171.

Choi, Y., Kale, R., \& Shin, J. (2010). Religiosity and consumers' use of product information source among Korean consumers: an exploratory research. International Journal of Consumer Studies, 34(1), 61-68.

Davis, L. (2009). Where to Shop? Exploring Chinese Consumers' Store Choice Criteria. Paper presented at the International Textile and apparel association (ITAA, 2009).

Dawson, J. (2000). Retailing at century end: some challenges for management and research. The International Review of Retail, Distribution and Consumer Research, 10(2), 119-148.

Devine, K. (2011). The Popularity of Religious Music and the Religiosity of Popular Music. Scottish Music Review, 2(1). 1-22.

Essoo, N., \& Dibb, S. (2004). Religious influences on shopping behaviour: An exploratory study. Journal of Marketing Management, 20(7), 683-712.

Fam, K. S., Waller, D. S., \& Erdogan, B. Z. (2004). The influence of religion on attitudes towards the advertising of controversial products. European Journal of Marketing, 38(5/6), 537-555.

Frishkopf, M. (2009). Globalizing the sound world: Islam and Sufi music in the West..Edmonton Canada:Routledge.

Gayatri, G., Hume, M., \& Mort, G. S. (2011). The role of Islamic culture in service quality research. Asian Journal on Quality, 12(1), 35-53.

Kocturk, T. (2002). Food rules in the Koran. Scandinavian Journal of Food \& Nutrition, 46(3), 137-139.

Mattila, A., \& Wirtz, J. (2001). Congruency of scent and music as a driver of in-store evaluations and behavior.Journal of Retailing, 77(2), 273-289.

McDaniel, S., \& Burnett, J. (1990). Consumer religiosity and retail store evaluative criteria. Journal of the Academy of Marketing Science, 18(2), 101-112.

Mitchell, V. W., \& Kiral, R. (1998). Primary and secondary store-loyal customer perceptions of grocery retailers. British Food Journal, 100(7), 312-319.

Mokhlis, S. (2006). The influence of religion on retail patronage behaviour in Malaysia. International Business Research, 3(1),70-75

Mokhlis, S. (2009). Relevancy and Measurement of Religiosity in Consumer Behavior Research. International Business Research, 2(3), 75.

Morschett, D., Swoboda, B., \& Foscht, T. (2005). Perception of store attributes and overall attitude towards grocery retailers: The role of shopping motives. The International Review of Retail, Distribution and Consumer Research, 15(4), 423-447.

Oppewal, H., \& Koelemeijer, K. (2005). More choice is better: Effects of assortment size and composition on assortment evaluation. International Journal of Research in Marketing, 22(1), 45-60.

Power, C. (2009). Halal: Buying Muslim: Time.Marketing, 12(1), 65-74.

Sarkissian, M. (2005). " Religion Never Had It so Good": Contemporary Nasyid and the Growth of Islamic Popular Music in Malaysia. Yearbook for traditional music, 124-152. 
eISSN: $2357-1330$

Selection and peer-review under responsibility of the Organizing Committee

Shabbir, M. S. (2010). The relationship between religiosity and new product adoption. Journal of Islamic Marketing, 1(1), 63-69.

Sood, J., \& Nasu, Y. (1995). Religiosity and nationality: An exploratory study of their effect on consumer behavior in Japan and the United States. Journal of Business Research, 34(1), 1-9.

Swimberghe, K., Sharma, D., \& Flurry, L. (2009). An exploratory investigation of the consumer religious commitment and its influence on store loyalty and consumer complaint intentions. Journal of Consumer Marketing, 26 (5),340-347 